\title{
Low and seasonal malaria transmission in the middle Senegal River basin: identification and characteristics of Anopheles vectors
}

\author{
Mamadou O Ndiath ${ }^{1 *}$, Jean-Biram Sarr ${ }^{2}$, Lobna Gaayeb ${ }^{3}$, Catherine Mazenot ${ }^{1}$, Seynabou Sougoufara ${ }^{1,4}$, \\ Lassana Konate ${ }^{4}$, Franck Remoue ${ }^{5}$, Emmanuel Hermann ${ }^{3,6}$, Jean-francois Trape ${ }^{1}$, Gilles Riveau ${ }^{3,6}$ and \\ Cheikh Sokhna'
}

\begin{abstract}
Background: During the last decades two dams were constructed along the Senegal River. These intensified the practice of agriculture along the river valley basin. We conducted a study to assess malaria vector diversity, dynamics and malaria transmission in the area.

Methods: A cross-sectional entomological study was performed in September 2008 in 20 villages of the middle Senegal River valley to evaluate the variations of Anopheles density according to local environment. A longitudinal study was performed, from October 2008 to January 2010, in 5 selected villages, to study seasonal variations of malaria transmission.

Results: Among malaria vectors, $72.34 \%$ of specimens collected were An. arabiensis, 5.28\% An. gambiae of the S molecular form, 3.26\% M form, 12.90\% An. pharoensis, 4.70\% An. ziemanni, 1.48\% An. funestus and 0.04\% An. wellcomei. Anopheles density varied according to village location. It ranged from 0 to 21.4 Anopheles/room/day and was significantly correlated with the distance to the nearest ditch water but not to the river.

Seasonal variations of Anopheles density and variety were observed with higher human biting rates during the rainy season (8.28 and 7.55 Anopheles bite/man/night in October 2008 and 2009 respectively). Transmission was low and limited to the rainy season (0.05 and 0.06 infected bite/man/night in October 2008 and 2009 respectively). During the rainy season, the endophagous rate was lower, the anthropophagic rate higher and L1014F kdr frequency higher.
\end{abstract}

Conclusions: Malaria vectors are present at low-moderate density in the middle Senegal River basin with An. arabiensis as the predominant species. Other potential vectors are An. gambiae $\mathrm{M}$ and $\mathrm{S}$ form and An. funestus. Nonetheless, malaria transmission was extremely low and seasonal.

Keywords: Malaria transmission, Anopheles arabiensis, Plasmodium infection, KDR mutation, Senegal River basin.

\section{Background}

In many African countries, food self-sufficiency is a goal that favors the development of irrigated areas. This strategy requires the management of water resources and the implementation of new hydro-agricultural arrangements. Northern Senegal (Senegal River basin) is located in a Sahelian area with low rainfall concentrated during the short rainy season between July and October

\footnotetext{
* Correspondence: ousmane.ndiatt@ird.fr

'Institut de Recherche pour le Développement, UMR 198 URMITE Campus international de Hann, IRD BP 1386 CP 18524 Dakar, Sénégal Full list of author information is available at the end of the article
}

(around $200 \mathrm{~mm} /$ year in 2008). During the 1980s', important development programs have been implemented including the construction of two dams on the Senegal River [1]. Following these developments, irrigated areas have been enlarged and rice culture expanded.

These ecological changes have largely promoted an increase in water-related diseases such as malaria, Rift Valley fever and schistosomiasis, [2,3]. In particular, changes in malaria vector densities were reported [4-6]. An. gambiae s.l. and An. funestus used to be the two main malaria vectors in this region; however, the latter disappeared after the 1970s' droughts [7]. In a study 
conducted in 1999, the first after dam construction, $A n$. funestus was again reported as the dominant species in the area [8]. The environmental changes associated with water development projects were suspected to be responsible for having created favourable conditions for the reestablishment of An. funestus.

After the implementation of the dams, water for irrigation was available; food crop was promoted in this area. Agricultural techniques changed and the use of insecticide increased. As in other African countries, this has contributed to the selection of resistant mosquito strains [9]. The presence of kdr mutation genotype, which has been recognized to be related to DDT and pyrethroid resistance [10] has been detected in various areas in Senegal [11].

This study was undertaken as part of the larger "AnoPal-AnoVac" study that aimed to determine whether exposure to Anopheles mosquitoes could alter humoral and cellular immune responses in children living in an area where malaria is present. In order to select study participants, an evaluation of exposure to Anopheles bites was undertaken in 20 villages. An entomological study was performed to provide up to date entomological information, describe the anophelian populations, their potential role as a vector of malaria and identify environmental factors affecting mosquito density.

\section{Methods}

\section{Study area}

The study was carried out in Northern Senegal, in 20 villages of the Senegal River basin (Agnam Towguel, Diatar, Dimat, Dioundou, Fanay Dierry, Gamadji Saré, Guédé Chantier, Guédé Village, Guia, Koditt, Mbantou, Ndiawara, Ndiayene Pendao, Ndierry Ba, Nénette, Niandane, Niaoulé, Njambou Soubalbé, Souima, Wouro Madiwou, Figure 1) representing an area of $70 \mathrm{~km}$ eastwest and $30 \mathrm{~km}$ north-south.

In this region, the climate is sahelian, with annual rainfall between July and October (340 $\mathrm{mm}$ in 2009). The mean temperature range between $20^{\circ} \mathrm{C}$ and $30^{\circ} \mathrm{C}$ during the cool season (November to February) and $25^{\circ}$ $\mathrm{C}$ to $38^{\circ} \mathrm{C}$ during the warm season (March to October). Vegetation is sparse, with few trees in and around villages. Domestic animals including cows, horses, donkeys,

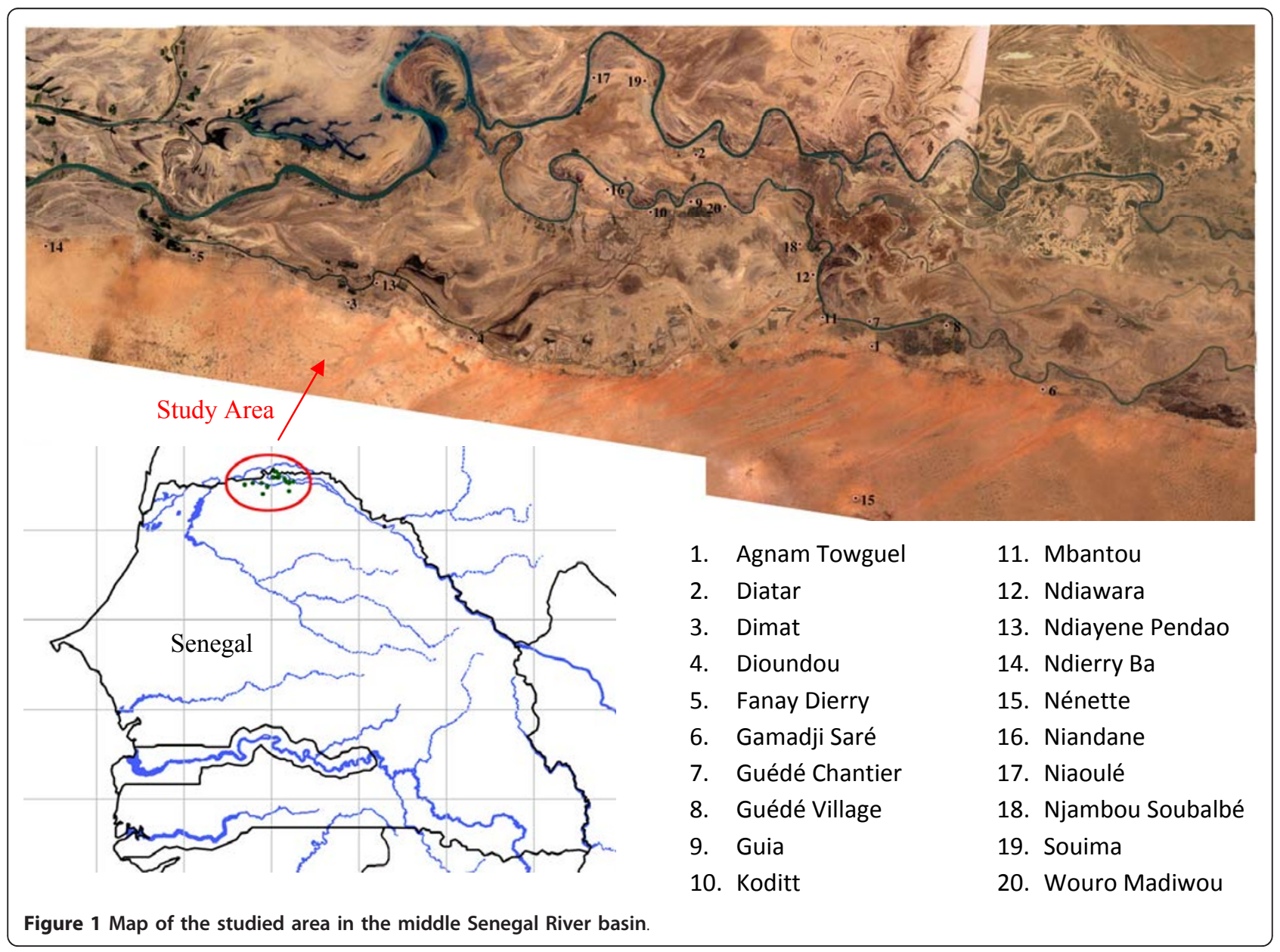


sheep and goats are usually bred in open enclosures near houses. The houses have mud walls with grass thatch or corrugated iron roofs.

In all villages, GPS coordinates of mosquitoes collection sites were recorded as well as coordinates of the nearest running water (Senegal River or large irrigation canal), ditch water (rice culture, brick production or cattle watering place) and temporary pools in flooded areas. The mean distance between sampling sites and water source were calculated. Villages were classified according to their geographical situation in Walo (flood areas: Agnam Towguel, Diatar, Dimat, Dioundou, Guédé Chantier, Guédé Village, Guia, Koditt, Mbantou, Niandane, Niaoulé, Wouro Madiwou) or Dierry (dry areas: Fanay Dierry, Guamadji Sarré, Ndiawara, Ndiayene Pendao, Ndierry Ba, Nénette, Njambou Soubalbé, Souima).

Prior to the study, permission was sought from the village elders; village meetings were conducted to explain the purpose of the study and participation requested. Verbal consent was obtained to collect mosquitoes from houses. Ethical approval was given by the Senegalese National Ethics Committee.

\section{Mosquito sampling}

Night landing catches (NLC) were performed from 19:00 to 07:00 hours. Four adult volunteer collectors were positioned at two different sites in each village. Two collected mosquitoes indoors and two outdoors. Pyrethrum spray catches (PSC) were conducted in five randomly selected rooms among those not having used any form of insecticide or repellent during the previous week and being different from those used for NLC. Deltamethrin $\left(\right.$ Yotox $^{\circledR}$ ) was sprayed inside the closed rooms for 30-45 seconds. After 10 minutes, dead or immobilized mosquitoes were collected. Anopheles species were identified using morphological characteristics according to identification rules [12]. Human Biting Rate (HBR) was estimated by the number of bites per person per night sampled by NLC.

\section{Study design}

The cross-sectional study was performed in September 2008 (in the middle of rainy season). PSC mosquitoes sampling was conducted for one day in $20 / 20$ villages and HLC for one night in $5 / 20$ villages.

For the longitudinal study, HLC were performed in five selected villages (Agnam Towguel, Fanay Dierry, Guédé Village, Ndiayene Pendao, Niandane) for two non consecutive nights and PSC for one day, both in October 2008, January 2009, May 2009, October 2009 and January 2010.

Endophagous rates were calculated as the proportion of the number of mosquitoes captured indoor to the total number of mosquitoes captured by HLC.

\section{Laboratory analyses}

Blood fed females captured by PSC had their blood meal squashed on Whatman No. 1 filter papers and tested by enzyme-linked immunosorbent assay (ELISA) to identify whether blood was of bovine, ovine, caprin (sheep and goat), equine (horse and donkey), or chicken origin [13]. Anthropophilic rate was calculated as proportion of blood-fed mosquitoes that had exclusively fed on human blood. All mosquitoes belonging to the An. gambiae complex were identified using the RFLP-PCR method using HhaI restriction enzyme [14]. The expression of Circumsporozoite Protein (CSP) was determined by performing ELISA with monoclonal antibodies against Plasmodium falciparum on the crushed head and thorax [15]. Infection rate was calculated as the proportion of positive mosquitoes to the total number of malaria vectors. Entomological inoculation rate (EIR) was calculated as the infection rate multiplied by HBR calculated for vectors species (An. gambiae s.l. and An. funestus). Detection of L1014F kdr mutation in An. gambiae s.l. was performed by PCR [16]. Both genotype and allelic frequencies were calculated.

\section{Statistical analyses of data}

Qualitative data were compared using Pearson $\mathrm{Chi}^{2}$ or Fisher exact test and quantitative data by non parametric tests (Spearman correlation, Kruskal-Wallis and Mann Whitney test) Statistical analyses were performed with Stata ${ }^{\circledR} 10.1$. A p value of 0.05 or less was considered as significant.

\section{Results}

From September 2008 to January 2010, 2426 Anopheles specimens were collected. Among these, 446 (18.38\%) were collected feeding on humans outdoors, 413 $(17.02 \%)$ were collected feeding on humans indoors and 1567 (64.59\%) were collected resting indoors. 1755 (72.34\%) were identified as An. arabiensis, 128 (5.28\%) An. gambiae molecular form S, 79 (3.26\%) molecular form M, 313 (12.90\%) An. pharoensis, 114 (4.70\%) An. ziemanni, 36 (1.48\%) An. funestus and 1 (0.04\%) An. wellcomei. All species were captured by HLC and all but An. wellcomei and An. ziemanni by PSC. An. arabiensis were present in all but one village (19), An. pharoensis in only 9, An. ziemanni and An. funestus in 6, An. gambiae molecular form $\mathrm{M}$ in 5, An. gambiae form $\mathrm{S}$ and An. wellcomei in 1.

\section{Cross-sectional study}

The presence and relative density of each species in the 20 villages is presented on Figure 2.

Since the density was highly variable between the villages, ranging from 0 in Gamadji Saré to 21.4 in Koditt, its environmental determinants were studied. The 


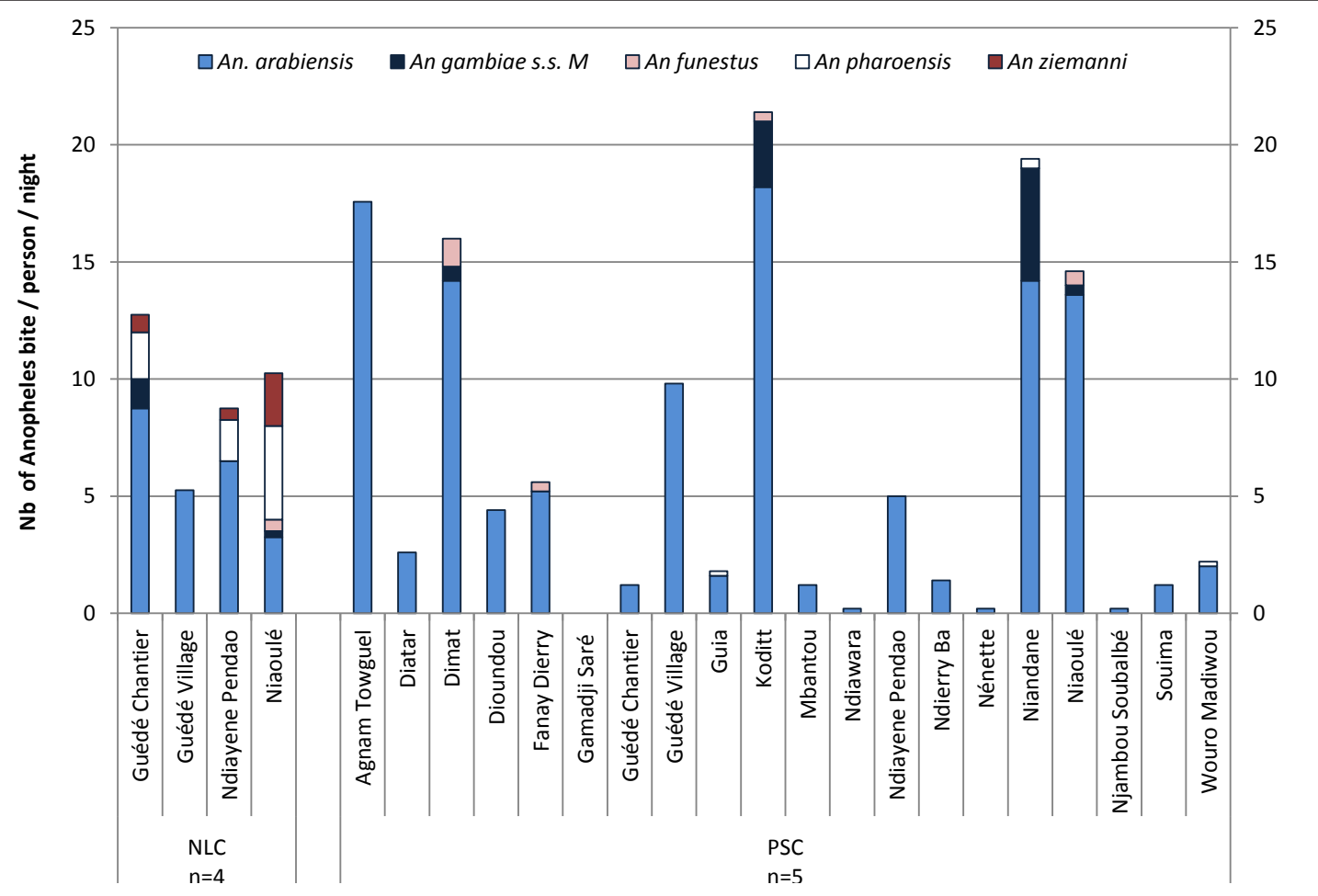

Figure 2 Anopheles density in the $\mathbf{2 0}$ villages of the study area during the cross-sectional study. Anopheles density measured in September 2008 by Night Landing Catches NLC (number of Anopheles/person/night, $\mathrm{n}=5$ person/night) and by Pyrethrum Spray Catches PSC (number of Anopheles/room/day, $\mathrm{n}=4 \mathrm{room} /$ day) in all villages according to the different species studied Anopheles funestus, Anopheles gambiae s.s. molecular form M, An. arabiensis, Anopheles pharoensis and Anopheles ziemanni).

distance between sampling sites in the village and river ranged from 0.11 to $11.08 \mathrm{~km}$ (mean $0.62 \pm 1.6)$ and was not correlated with Human Biting Rate (HBR) (Spearman rho $-0.05, \mathrm{p}=0.83)$. The distance to ditch water ranged from 0.14 to $3.9 \mathrm{~km}$ and was significantly correlated with HBR (Spearman rho -0.45, $\mathrm{p}<0.05$ ). In the villages classified as Walo (flooded areas), HBR was significantly higher than in villages classified as Dierry (dry area) (9.3 \pm 2.3 vs. $1.7 \pm 0.8$, Mann-Whitney test $\mathrm{p}=0.01$ ).

\section{Longitudinal study}

During the 16 month study period, the density, nature and relative proportion of Anopheles species collected varied according to the season (Figure 2). An. pharoensis and $A n$. ziemanni were collected in all seasons, $A n$. arabiensis was collected all year round except in June 2009. An. gambiae $\mathrm{M}$ and $\mathrm{S}$ forms were found only during the rainy season in October 2008 and October 2009 and $A n$. funestus was only collected during the rainy season in October 2009. HBR varied considerably according to the season (Figure 2); higher values were observed during the rainy season (8.28 Anopheles bite/man/night in October 2008) and (7.55 Anopheles bite/man/night in October 2009) and lower values during the dry season (0.30 in January 2009 and 0.65 in January 2010).
Specimens infected by Plasmodium were detected only among mosquitoes belonging to An. gambiae s.l.: 10/ 1055 An. arabiensis, 1/30 An. gambiae molecular form $\mathrm{M}$ and $3 / 128$ for the $\mathrm{S}$ form (Table 1). Infection rates did not vary significantly among the different species (Fisher exact $\mathrm{p}=0.09$ ). Among malaria vector species, global infection rate was $1.13 \%$. Circumsporozoite Protein (CSP) positive mosquitoes were mainly sampled during the rainy season but no significant variation in infection rate was observed (Fisher exact $\mathrm{p}=0.7$, Table 1). Transmission was seasonal with 0.047 and 0.059 infected bites per person and per night in October 2008 and October 2010 respectively. No transmission was observed between January and June 2009 (Figure 3).

Of the 711 specimens sampled by HLC, 327 (45.99\%) were collected indoors and 384 (54.01\%) outdoors. Significant variations in endophagous rate according to the season were observed $\left(\mathrm{Chi}^{2}=21.5, \mathrm{p}<0.001\right.$, Table 1$)$ with lower values during rainy seasons. There was a significant difference in endophagous behaviour among the different species (Fisher exact $\mathrm{p}<0.001$, Table 1 ).

Of the 340 blood meal samples tested, 46 (13.53\%) were from bovine or ovine origin (39 $(84.78 \%)$ bovine, 7 (15.22\%) ovine); $3(0.88 \%)$ were mixed human-ovine or human-bovine and 291 (85.59\%) were strictly of human 
Table 1 Main characteristics of Anopheles sampled during the longitudinal study

\begin{tabular}{|c|c|c|c|c|c|c|c|c|c|}
\hline \multirow[b]{2}{*}{ October 2008} & \multirow{2}{*}{$\begin{array}{c}\text { Mosquitoes collected } \\
784\end{array}$} & \multicolumn{2}{|c|}{$\begin{array}{c}\text { Indoor/Total } \\
\text { Endophagous rate } \\
\%\end{array}$} & \multicolumn{2}{|c|}{$\begin{array}{l}\text { Infected/total } \\
\text { Infection rate\% }\end{array}$} & \multicolumn{2}{|c|}{$\begin{array}{c}\text { Human blood meal/ } \\
\text { Total } \\
\text { Anthropophagic rate\% }\end{array}$} & \multicolumn{2}{|c|}{$\begin{array}{l}\text { L1014F kdr allele/total } \\
\text { frequency } \%\end{array}$} \\
\hline & & $132 / 331$ & $39.88 \%$ & $7 / 784$ & $0.89 \%$ & $164 / 181$ & $90.61 \%$ & $64 / 898$ & $7.13 \%$ \\
\hline January 2009 & 27 & $8 / 12$ & $66.67 \%$ & $0 / 27$ & $0.00 \%$ & $5 / 7$ & $71.43 \%$ & $0 / 38$ & $0.00 \%$ \\
\hline May 2009 & 161 & $30 / 40$ & $75.00 \%$ & $0 / 161$ & $0.00 \%$ & $31 / 43$ & $72.09 \%$ & $2 / 150$ & $1.33 \%$ \\
\hline October 2009 & 568 & $143 / 302$ & $47.35 \%$ & $6 / 568$ & $1.06 \%$ & $75 / 88$ & $85.23 \%$ & $77 / 608$ & $12.66 \%$ \\
\hline \multirow[t]{2}{*}{ January 2010} & 73 & $14 / 26$ & $53.85 \%$ & $1 / 73$ & $1.37 \%$ & $16 / 21$ & $76.19 \%$ & $9 / 104$ & $8.65 \%$ \\
\hline & & \multicolumn{2}{|c|}{$\begin{array}{c}\text { Chi2 }=21.5 p< \\
.0001\end{array}$} & \multicolumn{2}{|c|}{ Fisher exact $p=0.7$} & \multicolumn{2}{|c|}{ Fisher exact $p<0.01$} & \multicolumn{2}{|c|}{ Fisher exact $p<0.001$} \\
\hline An. funestus & 21 & $1 / 1$ & $100.00 \%$ & $0 / 21$ & $0.00 \%$ & $5 / 10$ & $50.00 \%$ & - & - \\
\hline An. arabiensis & 1055 & $139 / 313$ & $44.41 \%$ & 10/1055 & $0.95 \%$ & $247 / 285$ & $86.67 \%$ & $103 / 1486$ & $6.93 \%$ \\
\hline An. gambiae $M$ & 30 & $4 / 6$ & $67.67 \%$ & $1 / 30$ & $3.33 \%$ & $9 / 12$ & $75.00 \%$ & $3 / 60$ & $5.00 \%$ \\
\hline An. gambiae S & 128 & $15 / 41$ & $36.59 \%$ & $3 / 128$ & $2.34 \%$ & $30 / 32$ & $93.75 \%$ & $46 / 252$ & $18.25 \%$ \\
\hline An. pharoensis & 278 & $141 / 251$ & $56.18 \%$ & $0 / 278$ & $0.00 \%$ & 0/1 & $0.00 \%$ & - & - \\
\hline An. wellcomei & 1 & 0/1 & $0.00 \%$ & 0/1 & $0.00 \%$ & - & - & - & - \\
\hline \multirow[t]{2}{*}{ An. ziemanni } & 100 & $27 / 98$ & $27.55 \%$ & $0 / 100$ & $0.00 \%$ & - & - & - & - \\
\hline & & \multicolumn{2}{|c|}{$\begin{array}{l}\text { Fisher exact } \mathrm{p}< \\
\quad 0.001\end{array}$} & \multicolumn{2}{|c|}{$\begin{array}{l}\text { Fisher exact } p= \\
\quad 0.09\end{array}$} & \multicolumn{2}{|c|}{ Fisher exact $p=0.02$} & \multicolumn{2}{|c|}{ Chi2 $=36.6 p<0.001$} \\
\hline Total & 1613 & $327 / 711$ & $45.99 \%$ & $14 / 1613$ & $0.87 \%$ & $291 / 340$ & $85.59 \%$ & $152 / 1798$ & $8.45 \%$ \\
\hline
\end{tabular}

Number, endophagous rate, infection rate, anthropophagic rate and L1014F kdr allele frequency according to season and species during the longitudinal study from October 2008 to January 2010. Global comparison by Pearson Chi ${ }^{2}$ of Fisher exact test, $\mathrm{p}$ values are given.

origin. Significant variations in the anthropophilic rate were observed according to the season, with higher anthropophilic rates during the rainy season (Fisher exact $\mathrm{p}<0.01$, Table 1). Among species, there was a significant difference in anthropophagic rate (Fisher exact $\mathrm{p}=0.002$ ) with An. arabiensis and An. gambiae molecular form S being significantly more anthropophilic than An. funestus (Fisher exact $\mathrm{p}=0.008$ and 0.005 respectively).

Among An. gambiae s.l. specimens sampled, 899 were tested for the presence of kdr mutation. Homozygote

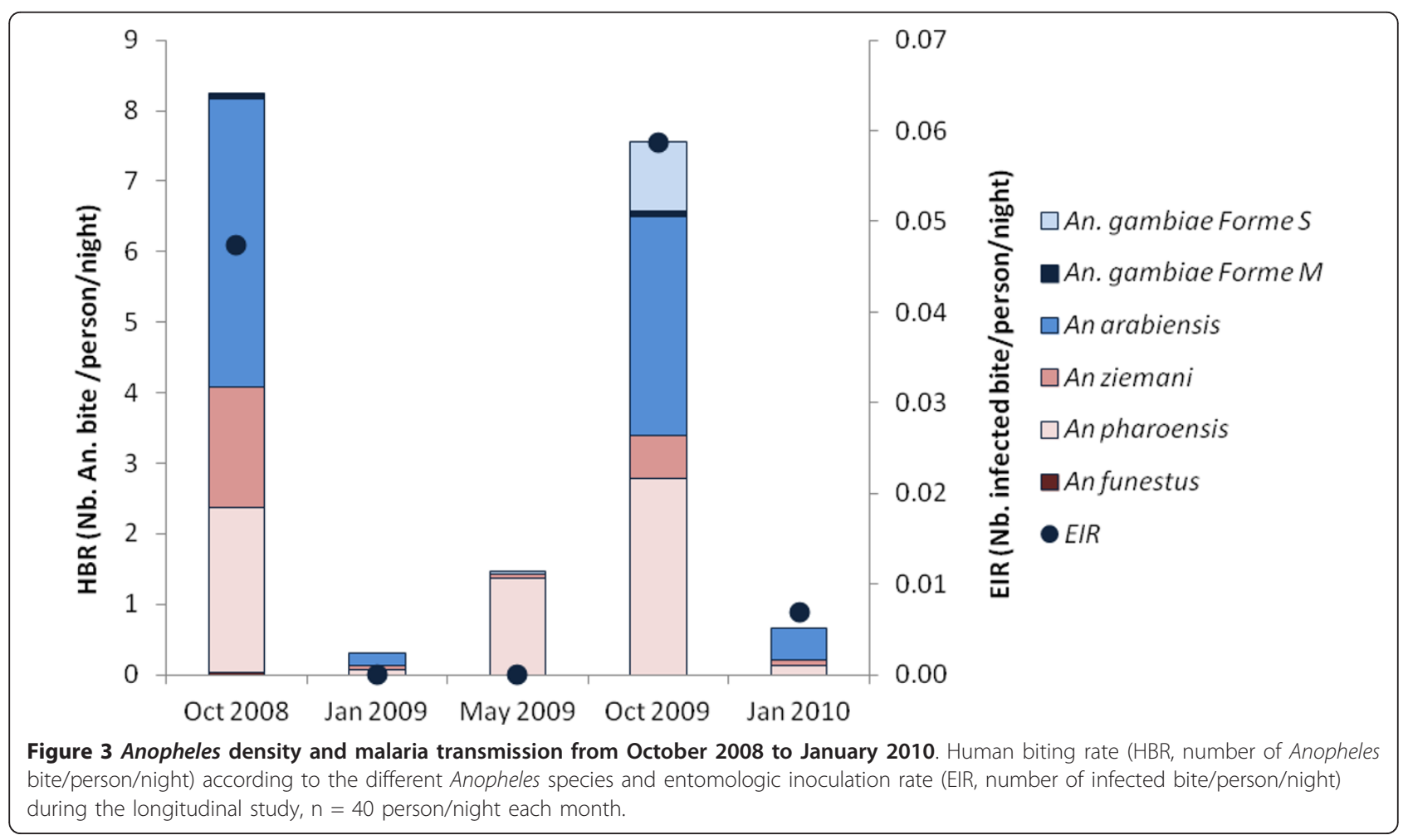


L1014F kdr mutation genotype was identified in 15 specimens $(1.7 \%)$, heterozygote L1014F $\mathrm{kdr}$ mutation in $122(13.6 \%)$ and homozygote wild genotype in 762 (84.8\%). L1014F kdr mutation allelic rate significantly changed according to the season (Fisher exact $\mathrm{p}<0.001$, Table 1) with higher values during the rainy seasons. L1014F kdr allelic frequency also varied according to the species (Pearson Chi $2=36.6, \mathrm{p}<0.001$ ) with the highest frequency observed in An. gambiae molecular form $\mathrm{S}$.

\section{Discussion}

The aim of this study was to identify and characterise potential malaria vector species in the middle Senegal River valley. A large variety of Anopheles was identified with seven sympatric species. While An. gambiae s.s. used to be the prevailing species in this region in the late 1990's [4], An. arabiensis was the most frequent species in this study and has been reported in all but one of the studied sites. It is known to be perfectly adapted to dry savannah areas where rainfall is low $[17,18]$. An. gambiae is known to be present and sympatric with $A n$. arabiensis in relatively dry regions like the Niger River in Mali or Mauritania [19], especially in rice culture areas [20]. Both $\mathrm{M}$ and $\mathrm{S}$ molecular forms of An. gambiae s.s. were identified in this study. These two molecular forms are known to be excellent malaria vectors [21], although the $\mathrm{S}$ form seems to be more susceptible to Plasmodium falciparum than the $M$ form [22]. The distribution of molecular forms $\mathrm{M}$ and $\mathrm{S}$ is influenced by environmental related factors and habitat characteristics. While An. gambiae M form needs permanent breeding sites provided by the presence of water such as in irrigation facilities or flooded areas [23,24], the S form is more strictly dependent on rainfall $[25,26]$. In this study, we observed the presence of both molecular forms $\mathrm{S}$ and $\mathrm{M}$ but only during rainy seasons. As previously reported in this region [5]An. pharoensis was identified in this study. An. pharoensis is known to be a potential malaria vector [6]. More surprising is the absence of $A n$. funestus in most villages and its low density all the year long. Appearance and disappearance of An. funestus seems a complex phenomenon that is still unsolved even though rainfall changes seem to be the main explanation [8,27]. In other areas, An. funestus density has been shown to be subject to seasonal variations associated with rice growth periods [28].

During the cross-sectional study, Anopheles densities were extremely variable between villages, being relatively high in some of them. Anopheles density was not related to the proximity of the river but to other ecological conditions: it was higher in villages situated in flooded areas (Walo) than in villages with sandy ground (Dierry) and was correlated to the presence of ditch water for various activities, such as rice culture, gardening, brick manufacturing or animal watering. Anopheles density was therefore more related to local man-made conditions than to a large scale geographical context.

Blood meal identification is important in understanding vectorial capacity of malaria vectors and transmission dynamics [29]. An. arabiensis is known to have an opportunistic feeding behaviour [30]. Anthropophily, in areas where $A n$. arabiensis predominates, may be high whether domestic animals are rare [31] or widely available [32]. An. arabiensis may also be highly zoophilic in other conditions [33,34]. In our study, An. arabiensis was highly anthropophilic, even though most of the householders kept cattle near their houses. Anthropophilic rates changed according to the season, with higher values in October, probably because most habitants of this region sleep outside during the hot season.

Although Anopheles density was high in some villages during the rainy season, CSP rate was low all the year round. Transmission only occurred during the rainy season and few months following. Similar infection rates have been reported in Dakar (Senegal) [35], Mauritania [36], Ethiopia [37] and Eritrea [38]. However, An. arabiensis sporozoite rates could be much higher in other villages or areas like Ndiop (Senegal) [39] or in Kenya [40]. Our data are in accordance with another study, indicating that ecological modifications of breeding sites influence mosquito density but not automatically malaria transmission [20]. As a result of the low transmission, malaria morbidity has been low in the Senegal River region in recent years (3 malaria attacks for 1000 inhabitants in 2009) [41].

The resistance of mosquitoes to DDT and pyrethroids, which have spread through sub-Saharan Africa during the last decades [42] has been recognized as being linked to the presence of knock-down resistance (kdr) mutation in An. gambiae s.l [10]. Although kdr mutation is only one among other mechanisms of resistance to insecticide, it is interesting to notice that it was present at low frequency in An. arabiensis and An. gambiae both molecular forms. Several studies have suggested that the use of agricultural pesticides favored the emergence and facilitated the spread of resistance within mosquito populations [43]. Although we did not specifically study this point, it is possible that changes in agricultural practice have contributed to the emergence of this resistance. A large scale implementation of insecticide treated nets (ITNs) is currently ongoing in Senegal [44]. The spread of resistance among mosquitoes could decrease the efficacy of this measure. On the other hand, the presence of ITNs can contribute to select resistant specimens as previously demonstrated in other areas [45]. 


\section{Conclusions}

In conclusion, malaria transmission in the middle Senegal River basin is low, seasonal and maintained by $A n$. arabiensis. Other vectors present in the area are $A n$. gambiae $\mathrm{M}$ and $\mathrm{S}$ forms and An. funestus. The abundance of malaria vectors during the rainy season favors malaria epidemics. The situation calls for the improvement of vector control initiatives during the rainy season.

\section{Acknowledgements}

We thank Gilles Chauvancy, Charles Bouganali, Ablaye Konaté and Soihibou Guindo for their technical assistance. We thank deceased Sidy Diongue, our guide during this study. We thank the EPLS Saint Louis and Kokou Abotsi for the logistic help.

Funding

This work integrated to Pal-Fleuve programme was supported by Espoir Pour La Sante (EPLS) GNO and the Research Institute for Development (IRD DVS Department). This work was also integrated in the EVIMalaR Network of Excellence funded by European Community (FP7-Health 2009). The FSD "Fonds Social de Developpement", (BIOMARQPAL ref 2008 - 5901) embassy of France in Senegal provided a financial participation. Jean Biram SARR was supported by a post-doctoral fellowship provided by the "Infectiopole Sud foundation" (Marseille, France).

\section{Author details}

'Institut de Recherche pour le Développement, UMR 198 URMITE Campus international de Hann, IRD BP 1386 CP 18524 Dakar, Sénégal. ${ }^{2}$ Institut de Recherche pour le Développement, UMR 224 MIVEGEC, 911 avenue Agropolis- BP 64501, F-34394 Montpellier, France. ${ }^{3}$ CIIL, Inserm U1019, CNRS UMR 8204, Université Lille Nord de France, Institut Pasteur de Lille, 1 rue du Pr. Calmette 59019 Lille cedex. ${ }^{4}$ Université Cheikh Anta Diop de Dakar, Département de Biologie Animale, BP 5005 Dakar, Sénégal. ${ }^{5}$ Institut de Recherche pour le Développement, UMR 224 MIVEGEC, Maladies infectieuses et vecteurs (UM1-UM2-CNRS 5290-IRD224), CREC 01BP 4414, Cotonou, Bénin. ${ }^{6}$ Centre Espoir pour la Santé, Laboratoire de Recherches Médicales BP: 226, Saint Louis Sénégal.

\section{Authors' contributions}

$J B S, F R, E H, L K$ and GR planned the study design. MON, SJB and LG performed field activity. MON and SS performed laboratory work. CM, MON analyzed the data, CM and CS drafted the manuscript. JFT and EH provided substantial improvement of the manuscript and CS and GR provided scientific supervision of the study. All authors approved the final version of the manuscript.

\section{Competing interests}

The authors declare that they have no competing interests.

Received: 23 November 2011 Accepted: 23 January 2012 Published: 23 January 2012

\section{References}

1. Handschumacher P, Hervé J-P, Hébrard G: Des aménagements hydroagricoles dans la valée du fleuve Sénégal ou le risque de maladies hydriques en milieu sahélien. Sécheresse 1992, 3:219-226

2. Ndiaye M: Le fleuve Sénégal et les barrages de l'OMVS:quels enseignements pour la mise en œuvre du NEPAD? VertigO - la revue électronique en sciences de l'environnement 2003.

3. Sow S, de Vlas SJ, Engels D, Gryseels B: Water-related disease patterns before and after the construction of the Diama dam in northern Senegal. Ann Trop Med Parasitol 2002, 96:575-586.

4. Faye O, Konate L, Mouchet J, Fontenille D, Sy N, Hebrard G, Herve JP. Indoor resting by outdoor biting females of Anopheles gambiae complex (Diptera: Culicidae) in the sahel of northern Senegal. J Med Entomol 1997, 34:285-289.
5. Carrara GC, Petrarca V, Niang M, Coluzzi M: Anopheles-Pharoensis and Transmission of Plasmodium-Falciparum in the Senegal River Delta, West-Africa. Med Vet Entomol 1990, 4:421-424.

6. Dia I, Konate L, Samb B, Sarr JB, Diop A, Rogerie F, Faye M, Riveau G, Remoue F, Diallo M, Fontenille D: Bionomics of malaria vectors and relationship with malaria transmission and epidemiology in three physiographic zones in the Senegal River Basin. Acta Tropica 2008, 105:145-153.

7. Faye O, Gaye O, Fontenille D, Hébrard G, Konate L, Sy N, Herve JP, Toure YT, Diallo S, Molez JF: Malaria decrease and drought in the Niayes area of northwestern Senegal. Cahiers santé 1995, 5:299-305.

8. Konate L, Diop A, Sy N, Faye MN, Deng Y, Izri A, Faye O, Mouchet J: Comeback of Anopheles funestus in Sahelian Senegal. Lancet 2001, 358:336.

9. Diabate A, Baldet T, Chandre F, Akoobeto M, Guiguemde TR, Darriet F, Brengues C, Guillet P, Hemingway J, Small GJ, Hougard JM: The role of agricultural use of insecticides in resistance to pyrethroids in Anopheles gambiae s.l. in Burkina Faso. Am J Trop Med Hyg 2002, 67:617-622.

10. Donnelly MJ, Corbel V, Weetman D, Wilding CS, Williamson MS, Black WC: Does kdr genotype predict insecticide-resistance phenotype in mosquitoes? Trends Parasitol 2009, 25:213-219.

11. Diop A: Rapports annuels du Projet OMS/GATES sur le contrôle et la biologie des vecteurs du paludisme. Programme National de Lutte contre le Paludisme, Ministère de la Santé et de la Prévention, Sénégal 2010.

12. Gillies MT, De Meillon D: The Anophelinae of Africa South of the Sahara (Ethiopian zoogeographical region)., $2343 \mathrm{pp}$.

13. Beier JC, Perkins PV, Wirtz RA, Koros J, Diggs D, Gargan TP, Koech DK Bloodmeal Identification by Direct Enzyme-Linked Immunosorbent-Assay (Elisa), Tested on Anopheles (Diptera, Culicidae) in Kenya. J Med Entomol 1988, 25:9-16

14. Fanello C, Santolamazza F, della TA: Simultaneous identification of species and molecular forms of the Anopheles gambiae complex by PCR-RFLP. Med Vet Entomol 2002, 16:461-464.

15. Wirtz RA, Zavala F, Charoenvit Y, Campbell GH, Burkot TR, Schneider I, Esser KM, Beaudoin RL, Andre RG: Comparative Testing of MonoclonalAntibodies Against Plasmodium-Falciparum Sporozoites for Elisa Development. Bull World Health Organ 1987, 65:39-45.

16. Martinez-Torres D, Chandre F, Williamson MS, Darriet F, Berge JB, Devonshire AL, Guillet P, Pasteur N, Pauron D: Molecular characterization of pyrethroid knockdown resistance $(\mathrm{kdr})$ in the major malaria vector Anopheles gambiae s.s. Insect Mol Biol 1998, 7:179-184.

17. Coetzee M, Craig M, le Sueur D: Distribution of African malaria mosquitoes belonging to the Anopheles gambiae complex. Parasitology Today 2000, 16:74-77.

18. Lindsay SW, Parson $\mathrm{L}$, Thomas CJ: Mapping the ranges and relative abundance of the two principal African malaria vectors, Anopheles gambiae sensu stricto and An-arabiensis, using climate data. Proc Biol Sci 1998, 265:847-854

19. Toure YT, Petrarca V, Traore SF, Coulibaly A, Maiga HM, Sankare O, Sow M, Dideco MA, Coluzzi M: Ecological Genetic-Studies in the Chromosomal Form Mopti of Anopheles-Gambiae S-Str in Mali, West-Africa. Genetica 1994, 94:213-223.

20. Diuk-Wasser MA, Toure MB, Dolo G, Bagayoko M, Sogoba N, Traore SF, Manoukis $\mathrm{N}$, Taylor CE: Vector abundance and malaria transmission in rice-growing villages in Mali. Am J Trop Med Hyg 2005, 72:725-731.

21. Ndiath MO, Brengues C, Konate L, Sokhna C, Boudin C, Trape JF, Fontenille D: Dynamics of transmission of Plasmodium falciparum by Anopheles arabiensis and the molecular forms $\mathrm{M}$ and $\mathrm{S}$ of Anopheles gambiae in Dielmo, Senegal. Malar J 2008, 7.

22. Ndiath MO, Cohuet A, Gaye A, Konate L, Mazenot C, Faye O, Boudin C, Sokhna C, Trape JF: Comparative susceptibility to Plasmodium falciparum of the molecular forms $\mathrm{M}$ and $\mathrm{S}$ of Anopheles gambiae and Anopheles arabiensis. Malar J 2011, 10:269.

23. de SD, Kelly-Hope L, Lawson B, Wilson M, Boakye D: Environmental factors associated with the distribution of Anopheles gambiae s.s in Ghana; an important vector of lymphatic filariasis and malaria. PLoS One 2010, 5 e9927.

24. Toure YT, Petrarca V, Traore SF, Coulibaly A, Maiga HM, Sankare O, Sow M, Di Deco MA, Coluzzi M: The distribution and inversion polymorphism of chromosomally recognized taxa of the Anopheles gambiae complex in Mali, West Africa. Parassitologia 1998, 40:477-511. 
25. Yawson AE, McCall PJ, Wilson MD, Donnelly MJ: Species abundance and insecticide resistance of Anopheles gambiae in selected areas of Ghana and Burkina Faso. Med Vet Entomol 2004, 18:372-377.

26. Diabate A, Baldet T, Chandre C, Dabire KR, Kengne P, Guiguemde TR, Simard F, Guillet P, Hemingway J, Hougard JM: KDR mutation, a genetic marker to assess events of introgression between the molecular $M$ and $\mathrm{S}$ forms of Anopheles gambiae (Diptera: Culicidae) in the tropical savannah area of West Africa. J Med Entomol 2003, 40:195-198.

27. Mouchet J, Faye O, Julvez J, Manguin S: Drought and malaria retreat in the Sahel, West Africa. Lancet 1996, 348:1735-1736.

28. Sogoba N, Vounatsou P, Doumbia S, Bagayoko M, Toure MB, Sissoko IM, Traore SF, Toure YT, Smith T: Spatial analysis of malaria transmission parameters in the rice cultivation area of Office du Niger, Mali. Am J Trop Med Hyg 2007, 76:1009-1015.

29. Rosenberg R, Wirtz RA, Lanar DE, Sattabongkot J, Hall T, Waters AP, Prasittisuk C: Circumsporozoite Protein Heterogeneity in the Human Malaria Parasite Plasmodium-Vivax. Science 1989, 245:973-976.

30. Lemasson JJ, Fontenille D, Lochouarn L, Dia I, Simard F, Ba K, Diop A, Diatta M, Molez JF: Comparison of behavior and vector efficiency of Anopheles gambiae and An-arabiensis (Diptera: Culicidae) in Barkedji, a Sahelian area of Senegal. J Med Entomol 1997, 34:396-403.

31. Himeidan YE, Dukeen MY, El-Rayah E-A: Anopheles arabiensis: abundance and insecticide resistance in an irrigated area of eastern Sudan. East Mediterr Health J 2004, 10:167-174.

32. Mwangangi JM, Mbogo CM, Nzovu JG, Githure JI, Yan GY, Beier JC: Bloodmeal analysis for anopheline mosquitoes sampled along the Kenyan coast. J Am Mosa Control Assoc 2003, 19:371-375.

33. Ameneshewa B, Service MW: Blood-feeding behavior of Anopheles arabiensis Patton (Diptera: Culicidae) in central Ethiopia. Ethiopia J Afr Zoo 2011, 11:235-245.

34. Boreham PFL: Some Applications of Bloodmeal Identifications in Relation to Epidemiology of Vector-Borne Tropical Diseases. J Trop Med Hyg 1975, 78:83-91.

35. Machault V, Gadiaga L, Vignolles C, Jarjaval F, Bouzid S, Sokhna C, Lacaux JP, Trape JF, Rogier C, Pages F: Highly focused anopheline breeding sites and malaria transmission in Dakar. Malar J 2009, 8.

36. Dia I, Ba H, Mohamed SAO, Diallo D, Lo B, Diallo M: Distribution, host preference and infection rates of malaria vectors in Mauritania. Parasit Vectors 2009, 2.

37. Fettene M, Hunt RH, Coetzee M, Tessema F: Behaviour of Anopheles arabiensis and An. quadriannulatus sp B mosquitoes and malaria transmission in southwestern Ethiopia. African Entomol 2004, 12:83-87.

38. Waka M, Hopkins RJ, Akinpelu O, Curtis C: Transmission of malaria in the Tesseney area of Eritrea: parasite prevalence in children, and vector density, host preferences, and sporozoite rate. J Vec Ecol 2005, 30:27-32.

39. Fontenille D, Lochouarn L, Diatta M, Sokhna C, Dia I, Diagne N, Lemasson JJ, Ba K, Tall A, Rogier C, Trape JF: Four years' entomological study of the transmission of seasonal malaria in Senegal and the bionomics of Anopheles gambiae and A-araibiensis. Trans $R$ Soc Trop Med Hyg 1997, 91:647-652.

40. Joshi GP, Service MW, Pradhan GD: Survey of Species-A and Species-B of Anopheles-Gambiae Giles Complex in Kisumu Area of Kenya Prior to Insecticidal Spraying with Oms-43 (Fenitrothion). Ann Trop Med Parasitol 1975, 69:91-104.

41. Ministère de la Santé et de la Prévention: Annual report. National Malaria Managment Programm 2009

42. Ranson H, N'Guessan R, Lines J, Moiroux N, Nkuni Z, Corbel V: Pyrethroid resistance in African anopheline mosquitoes: what are the implications for malaria control? Trends Parasitol 2011, 27:91-98.

43. Diabate A, Brengues C, Baldet T, Dabire KR, Hougard JM, Akogbeto M, Kengne P, Simard F, Guillet P, Hemingway J, Chandre F: The spread of the Leu-Phe kdr mutation through Anopheles gambiae complex in Burkina Faso: genetic introgression and de novo phenomena. Trop Med Int Health 2004, 9:1267-1273.

44. Thwing Jl, Perry RT, Townes DA, Diouf MB, Ndiaye S, Thior M: Success of Senegal's first nationwide distribution of long-lasting insecticide-treated nets to children under five - contribution toward universal coverage. Malar J 2011, 10:86.

45. Czeher C, Labbo R, Arzika I, Duchemin JB: Evidence of increasing Leu-Phe knockdown resistance mutation in Anopheles gambiae from Niger following a nationwide long-lasting insecticide-treated nets implementation. Malar J 2008, 7.

doi:10.1186/1756-3305-5-21

Cite this article as: Ndiath et al:: Low and seasonal malaria transmission in the middle Senegal River basin: identification and characteristics of Anopheles vectors. Parasites \& Vectors 2012 5:21.

\section{Submit your next manuscript to BioMed Central and take full advantage of:}

- Convenient online submission

- Thorough peer review

- No space constraints or color figure charges

- Immediate publication on acceptance

- Inclusion in PubMed, CAS, Scopus and Google Scholar

- Research which is freely available for redistribution

Submit your manuscript at www.biomedcentral.com/submit
Biomed Central 